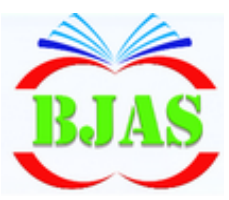

ISSN $1814-5868$
Available online at http://journal.bajas.edu.iq

College of Agriculture, University of Basrah

DOi:10.21276/basjas

Basrah J. Agric. Sci., 32(2): 1-6, 2019
Basrah Journal

of Agricultural

Sciences

E-ISSN: 2520-0860

\title{
Use of RAPD Markers Technique to Evaluate Genetic Variation in Two
}

\section{Types of Local Ducks}

\author{
Mareb A. Al-Kurdi, Sajida. A. Al-Shaheen \& Majid H. Al-Asadi \\ Department of Animal Production, College of Agriculture, University of Basrah, Iraq \\ *Corresponding author e-mail: amarib998@gmail.com \\ Received 15 December 2018; Accepted 15 January 2019; Available online 27 October 2019
}

\begin{abstract}
This study was carried out to assess the genetic variation between two local Iraqi (white and grey) ducks by RAPD-PCR technique using five random primers. The total number of bands that shown by the primers (APO-08, APOF-O9, APO-10, APO16, APO-18) was 63, 53, 79, 81, 68 for local white ducks, while it was 62, 61, 66, 69, 58 for the local gray ducks respectively. Additionally, all primers showed 59 common bands. OPA-08 primer showed the highest number of common bands (22) while APF09 primer resulted the lowest number of common bands ( 4 bands). The overall number of specific bands in local white ducks were higher than those of local grey ducks (285 and 257 bands, respectively). The average of similarity ratio between local ducks was (35.76) while individually, APO-08 primer showed the highest similarity ratio $(70.4 \%)$ comparing with the lowest similarity percentage (14.04\%) that represented by OPF-09 primer.
\end{abstract}

Keywords: Genetic variation, Polymorphism, RAPD Markers, Ducks.

\section{Introduction}

Ducks are considered as a resource of income and food for people all over the world and the global consumption of ducks birds ranged between (4-5\%) of the total poultry products (FAO, 2014). Its consumption has increased rapidly over the past decade as a diet rich in protein quality, energy, vitamins, minerals and unsaturated fatty acids and therefore is preferred by the consumers (MIFFAF, 2013).There is a recent interest in research and development of ducks production, and thus in duck breeding. In Iraq, local ducks are adapted to living in simple conditions and should therefore be considered as important resources for poultry production, when their genetic composition are studied. Breeding needs information on genetic background about ducks in Iraq, particularly the genetic variation. In fact, very few reports are available about genetic information on duck populations. Advances techniques in molecular biology provided the base for revealing virtually infinite types of DNA markers to analyze the genetic diversity among different breeds and species in order to preserve as source of natural wealth in most 


\section{Al-Kurdi et al. / Basrah J. Agric. Sci., 32(2): 1-6}

of the developed countries (Sharma et al., 2015). The RAPD-PCR technique is one of PCR reaction that randomly amplify segments of DNA and it applied to study genetic similarity, diversity and relationship among different avian species such as ducks(Su et al.,2006).This technique is simple and helped in comparing genomic DNA of various organisms that were evolutionarily separated (Kumar \& Gurusubramanian, 2011). Accordingly, due to the low number of studies on local ducks, its characteristics in terms of productive traits for getting enough information to build an integrated accurate database about it., especially in the genetic variation field. So, the goal of this study was to assess the genetic polymorphism between white and gray domestic ducks using RAPDPCR technique as genetic markers.

\section{Materials and Methods:}

This study was carried out in the genetic engineering lab, Animal production Department, College of Agriculture, Basrah University. Thirty blood samples were collected (after slaughtering the birds of the local white and grey ducks at 12 weeks of age) in sterilized tubes containing EDTA, then preserved at $-20 \mathrm{c}$ until use. Genomic DNA was extracted using DNA purification kit according to the manufacturer protocol. The quality of DNA was determined by agarose gel electrophoresis. The quantity of DNA was determined by Nano-drop device (Thermo-scientific TM, USA) under 260/280 $\mathrm{nm}$ wave-length. Five arbitrary short primers were tested on pooled DNA samples (Table $1)$.

The RAPD-PCR reaction was performed in $20 \mu \mathrm{l}$ volume containing $1.5 \mu \mathrm{l}$ primer, $6.5 \mu \mathrm{l}$ dd-H2o,2 $\mu 1$ template DNA and $10 \mu 12 x$ Taq master mix. Amplification was carried out in $\mathrm{T}$ professional thermal cycler with the following condition: initial denaturation at $95 \mathrm{c}$ for 3 minutes, followed by 40 cycles (denaturation at $95 \mathrm{c}$ for 1 minute, annealing at $32 \mathrm{c}$ for 1 minute, extension at $72 \mathrm{c}$ for 1.5 minutes) and 7 minutes at $72 \mathrm{c}$ for final extension. The amplified fragments were run on $1.5 \%$ agarose gel. The gel was photographed and analyzed through gel documentation system (Bio Doc Analyse, Biometra, Germany). The PCR products were scored across the lanes, the presence or absence of distinct bands were recorded as (1) and (0) respectively, in RAPD profile of local white and grey ducks. Patterns between different duck types were compared using the similarity ratio which reflects the extents of band sharing and calculated using the formula (Lynch,1990)

$\mathrm{BS}=2 \mathrm{~N}_{\mathrm{ab}} /\left(\mathrm{N}_{\mathrm{a}}+\mathrm{N}_{\mathrm{b}}\right)$

Where;

$\mathrm{N}_{\mathrm{ab}}$ are the number of bands shared by individual $\mathrm{a}$ and $\mathrm{b}$.

$\mathrm{N}_{\mathrm{a}}$ and $\mathrm{N}_{\mathrm{b}}$ are the total number of fragments scored in individual a and $\mathrm{b}$, respectively.

BS values were calculated for each primer separately and the average for all primers was carried out with each comparison.

\section{Results \& Discussion}

The RAPD-PCR results revealed that OPA-16 primer produced the highest number of bands 81 in white ducks and 69 in grey ducks, While the OPF-09 and OPA-18 primers showed the lowest number of bands in both white and grey ducks, (53 and 58 bands respectively; Fig. 1). 
Al-Kurdi et al. / Basrah J. Agric. Sci., 32(2): 1-6

Table (1): The primers used in the (RAPD-PCR) technique (El-Araby \&Saleh, 2016).

\begin{tabular}{|c|c|c|}
\hline & Primers & Sequence of Primer \\
\hline $\mathbf{1}$ & OPA-08 & 5'GTGACGTAGG'3 \\
\hline $\mathbf{2}$ & OPF-09 & 5'CCAAGCTTCC'3 \\
\hline $\mathbf{3}$ & OPA-10 & 5'GTGATCGCAG'3 \\
\hline $\mathbf{4}$ & OPA-16 & 5'AGCCAGCGAA'3 \\
\hline $\mathbf{5}$ & OPA-18 & 5'AGGTGACCGT'3 \\
\hline
\end{tabular}

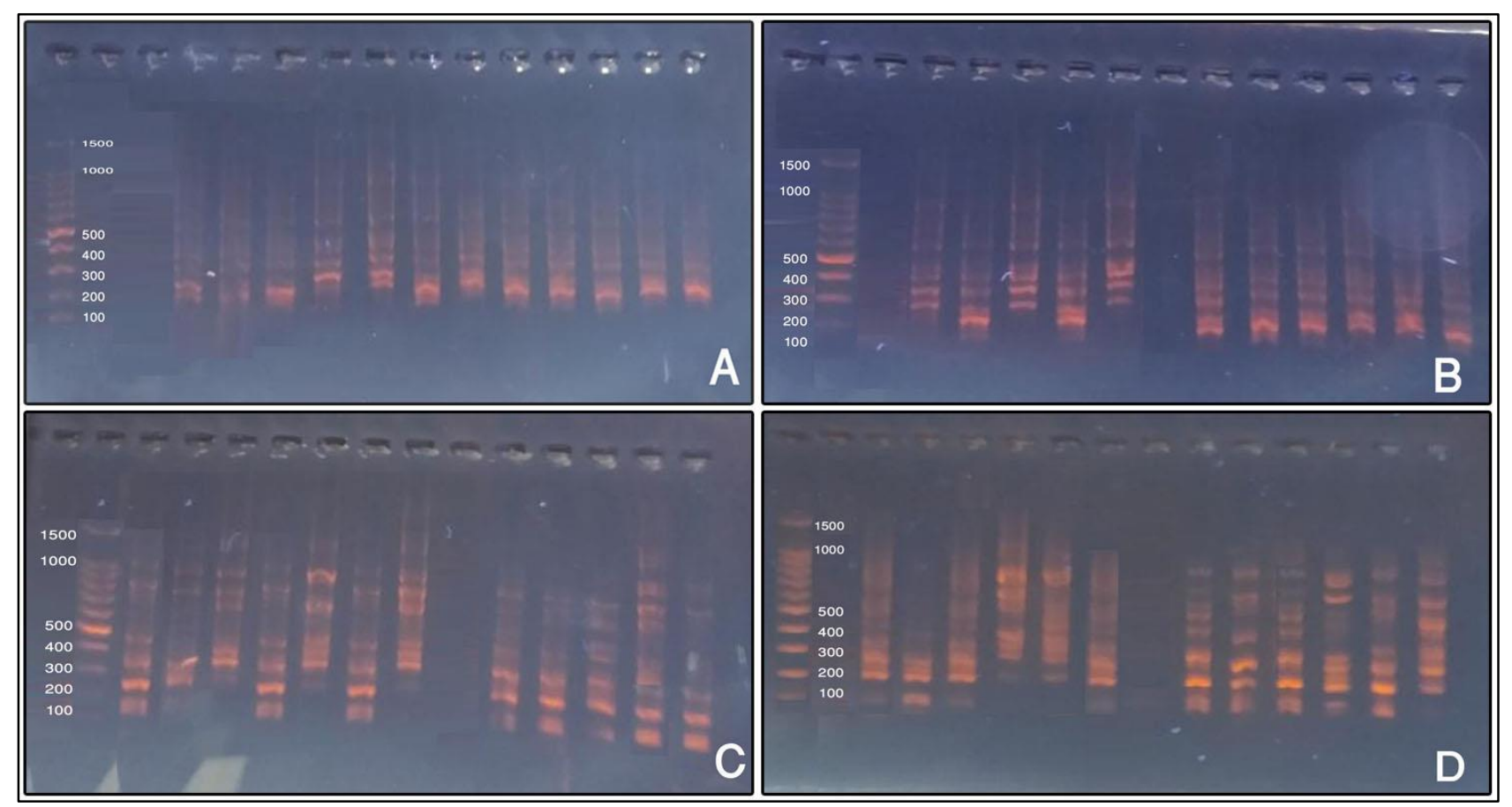

Fig. (1): A: Amplification of OPF-09 primer in local grey ducks, B: Amplification of OPF-09 primer in local white ducks, C: Amplification of OPA-16 primer in local grey ducks, D: Amplification of OPA-16 primer in local white ducks. M: Volumetric guide (Ladder).

\section{Specific, common and total bands}

Table (2) shows the results of the specific, common and total bands. The total number of bands produced by all primers were 344 in white ducks and 316 in grey ducks. Among them, 285 specific bands appeared in white ducks while 257 specific bands presented in grey ducks. These results did not correspond to the results obtained by El-Araby \& Saleh (2016) who used 13 primers that showed 92 of the total bands, in the rate of (40.2\%) of specific bands. Additionally, our results revealed that there were 59 similar bands between local white and grey ducks that produced by all primers. Our study did not agree with the finding of Basha et al. (2016) when he studied three breeds of ducks (Sudanese, Muscovy and white Pekini). So, they found 15, 12 and 22 specific bands for Pekini, Sudanese, and Muscovy ducks., respectively. While in another study on 


\section{Al-Kurdi et al. / Basrah J. Agric. Sci., 32(2): 1-6}

Muscovy ducks reared in two different environments, Ogan et al. (2014) found that the total numbers of bands were 59 and 54 and the numbers of polymorphic bands were
19, 16 for Guinea Savannah and Rain Forest ducks, respectively. Whereas the numbers of specific bands were 40 and 38 , respectively.

Table (2): Number of specific, common and total bands for the local white and grey ducks.

\begin{tabular}{|l|c|c|c|c|c|c|}
\hline \multirow{2}{*}{ The primers } & \multicolumn{3}{|c|}{ White ducks } & \multicolumn{3}{c|}{ Grey ducks } \\
\cline { 2 - 7 } & $\begin{array}{c}\text { specific } \\
\text { bands }\end{array}$ & $\begin{array}{c}\text { common } \\
\text { bands }\end{array}$ & $\begin{array}{c}\text { Total } \\
\text { bands }\end{array}$ & $\begin{array}{c}\text { specific } \\
\text { bands }\end{array}$ & $\begin{array}{c}\text { common } \\
\text { bands }\end{array}$ & Total bands \\
\hline OPA-08 & 41 & 22 & 63 & 40 & 22 & 62 \\
\hline OPF-09 & 49 & 4 & 53 & 57 & 4 & 61 \\
\hline OPA-10 & 68 & 11 & 79 & 55 & 11 & 66 \\
\hline OPA-16 & 67 & 14 & 81 & 55 & 14 & 69 \\
\hline OPA-18 & 60 & 8 & 68 & 50 & 8 & 58 \\
\hline Total & 285 & 59 & 344 & 257 & 59 & 316 \\
\hline
\end{tabular}

The ratio of similarity between local White and Grey ducks

Table (3) showed the ratio of similarity (\%) between local white and grey ducks for all primers. It is clear from the results that the average of similarity was $35.76 \%$. The highest ratio of similarity was achieved by primer (OPA-08) while the lowest ratio of similarity was presented by (OPF-09) primer (70.4 and 14.04, respectively).

Table (3): The ratio of similarity (\%) between local white and grey ducks for all primers.

\begin{tabular}{|c|c|}
\hline The primers & Similarity (\%) \\
\hline OPA-08 & 70.4 \\
\hline OPF-9 & 14.04 \\
\hline OPA-10 & 30.34 \\
\hline OPA-16 & 37.33 \\
\hline OPA-18 & 25.39 \\
\hline Average & 35.76 \\
\hline
\end{tabular}

It is clear from the results that the variation between white and grey domestic ducks were higher than the ratio of similarity and this result indicates the possibility of preserving them as a source of genetic diversity.
This study did not agree with the finding of El-Gendy et al. (2005) who found in his study that among five strains of ducks the average values of genetic variation within the strains was 0.38 while the genetic similarity was 0.73 .

\section{Genetic polymorphism (\%)}

Table (4) showed the number of monomorphic and polymorphic bands and the genetic polymorphism (\%) of local white and grey ducks. It is noted from the table that the percentage of polymorphism of local White and Grey ducks were 98.54 and $98.41 \%$, respectively. Furthermore, OPA-16 primer showed the highest percentage of genetic polymorphism $(98.76 \%)$ whereas the lowest percentage emerged by OPF-09 primer $(98.11 \%)$ in white ducks and the primer OPA16 showed the highest percentage of genetic polymorphism $(98.55 \%)$, while the lowest percentage of the polymorphism was by the primer OPA-18 which reached to $98.27 \%$ in grey ducks. Basha et al. (2016) studied three breeds of ducks (Sudanese, Muscovy, white Pekini) by using 19 primers and found that amplification process resulted in $(89.14 \%)$ of polymorphism from 169 polymorphic bands 


\section{Al-Kurdi et al. / Basrah J. Agric. Sci., 32(2): 1-6}

while El-Araby \& Saleh (2016) found that of the polymorphic bands were 55 bands and the percentage of polymorphism was (59\%). As the primer OPC1 showed the highest percentage of polymorphic bands (100\%) while the primer OPA-18 produced the lowest percentage of the polymorphic bands (37.5\%). On the other hand, Kulikova et al. (2003); Li et al. (2006) noted that the percentage of genetic polymorphism in the wild and local ducks in Russia ranged between (80-50\%). Whereas, Alyehhodi et al. (2010) found the total number of bands in Indian Moti ducks has reached 127 bands and the percentage of polymorphic bands was (69.8\%). Furthermore, the rate of genetic polymorphism in another study was (70\%) in one breed of Indian ducks (Sankhyan, 2007).

Table (4): The number of monomorphic and polymorphic bands and genetic polymorphism (\%) for local white and grey duck.

\begin{tabular}{|c|c|c|c|c|c|c|}
\hline \multirow{2}{*}{$\begin{array}{l}\text { The } \\
\text { primers }\end{array}$} & \multicolumn{3}{|c|}{ White ducks } & \multicolumn{3}{|c|}{ Grey ducks } \\
\hline & $\begin{array}{l}\text { monomorphic } \\
\text { bands }\end{array}$ & $\begin{array}{l}\text { Polymorphic } \\
\text { bands }\end{array}$ & $\begin{array}{c}\text { Genetic } \\
\text { polymorphism } \\
(\%)\end{array}$ & $\begin{array}{l}\text { monomorphic } \\
\text { bands }\end{array}$ & $\begin{array}{l}\text { Polymorphic } \\
\text { bands }\end{array}$ & $\begin{array}{c}\text { Genetic } \\
\text { polymorphism } \\
(\%)\end{array}$ \\
\hline OPA-08 & 1 & 62 & 98.41 & 1 & 61 & 98.38 \\
\hline OPF-09 & 1 & 52 & 98.11 & 1 & 60 & 98.36 \\
\hline OPA-10 & 1 & 78 & 98.73 & 1 & 65 & 98.48 \\
\hline OPA-16 & 1 & 80 & 98.76 & 1 & 68 & 98.55 \\
\hline OPA-18 & 1 & 67 & 98.52 & 1 & 57 & 98.27 \\
\hline Total & 5 & 339 & 98.54 & 5 & 311 & 98.41 \\
\hline
\end{tabular}

\section{Conclusions}

The result of this study indicated the presence of clear contrast between the two local ducks, which contributes to the possibility of preserving them as a source of genetic diversity in Iraq.

\section{Acknowledgements}

We thank the team of laboratory of Genetic Engineering, College of Agriculture and all who helped me in this work.

Conflict of interest: The authors declare that they have no conflict of interest.

Ethical approval: all applicable national and international guidelines for the care and use of animals were followed.

\section{References}

Alyehhodi, R.R.; Kumar, S.; Panda, B.K.; Singh, P.; Choudhary, S. \& Jaiswal, G. (2010). Molecular genetic characterization of Moti native duck using RAPD markers. J. Appl. Anim. Res., 37(1): 1923.

Basha, H.A., Abd el Naby, W.S.H \& Heikal, H.S. (2016). Genetic diversity and phylogenetic relationship among three duck breeds and geese using RAPD. markers. Adv. Anim. Vet. Sci., 4(9): 462467.

Dunnington, E.A.; Plotsky., Y.H.; Aberfeld, A.; Kirls, T.; Goldberg, A.; Lavi, V.; Cohanes, A.; Siegel, P.B. \& Hillel, J. (1990). DNA fingerprinting chickens selected for high and low body weight for 31 generation. J. Anim. Genet., 21: 247257. 


\section{Al-Kurdi et al. / Basrah J. Agric. Sci., 32(2): 1-6}

El-Araby, I.E. \& Saleh, A.A. (2016). Assessment of phylogenetic relationship and genetic variability among some duck breeds Using RAPD-PCR as Molecular Markers. Alexandria J. Vet. Sci., 51(1): 174-179.

El-Gendy, E.A.; Helal, M.A.; Goher, N.H \& Mostageer, A. (2005). Molecular characterization of genetic biodiversity in ducks, using RAPD-PCR analysis. Arab J. Biotech., 8(2): 253-264.

FAO (2014). FAO statistical yearbook: Africa Food and Agriculture, Accra: 168pp.

Gilbert, D.A.; Lehman, N.D.; Brien, S.J. \& Wayne, R.K. (1990). Genetic Fingerprinting reflects population difference in the California channel island fox. Nature, 344: 764-766.

Kulikova, I.V.; Chelomina, G.N. \& Zhuravlev, Y.N. (2003). Low genetic differentiation of and close evolutionary relationships between Anas platyrhynchos and Anas poecilorhyncha: RAPD-PCR Evidence. Russ. J. Genet., 39(10): 11431151.

Kumar, N.S. \& Gurusubramanian, G. (2011). Random amplified polymorphic DNA (RAPD) markers and its applications. Sci. Vis., 11(3): 116-124.

Li, H.; Yang, N.; Chen, K.; Chen, G., Tang, Q.; Tu, Y.; \& Ma. Y. (2006). Study on molecular genetic diversity of native duck breeds in China. World's Poult. Sci. J., 62(4): 603-611.

Lynch, M. (1990). The similarity index and DNA fingerprinting. Mol. Bio. Evol.,7: 478-484.

MIFFAF (Ministry for Food, Agriculture, Forestry). (2013). Primary Statistics of food, Agriculture, Forestry and Fisheries, Sejong, Korea.

Nei, M. (1972). Genetic distance between populations. Am. Nat., 106(949): 283-292.

Nelson K. \& Soule, M. (1987). Genetical conservation of exploited fishes. 345-368 In: Ryman, N. \& Utter, F. (Eds.). Population genetics and fishery management. Univ. Washington Press. 418pp.

Ogah, D.M. \& Momoh, O.M. (2014). Analysis of genetic diversity of Nigeria indigenous Muscovy duck ecotypes using RAPD Marker. PAT., 10(2): 225-232.

Sankhyan, V. (2007). Molecular genetic characterization of Indian runner native duck. M. Sc. Thesis. Indian Vet. Res. Inst. Izantngar. (cited from Basha et al., 2016)

Sharma R..; Kishore, A.; Mukesh M.; Ahlawat S.; Maitra A.; Pandey A.K. \& Tantia, M.S. (2015). Genetic diversity and relationship of Indian cattle inferred from microsatellite and mitochondrial DNA markers. BMC Genetics, 16: 1-12. 